\title{
Feeding of Excessive Cystine and Cysteine Enhances Defects of Dietary Copper Deficiency in Rats by Differential Mechanisms Involving Altered Iron Status
}

\author{
Qin WAN, Ben-Shan YANG, and Norihisa KATO* \\ Department of Applied Biochemistry, Faculty of Applied Biological Science, \\ Hiroshima University, Higashi-Hiroshima 739, Japan
}

(Received November 12, 1995)

\begin{abstract}
Summary We have reported that excess cystine feeding exaggerates the defects of dietary copper deficiency in rats by a mechanism not involving oxidative stress and altered copper status. This study was conducted to examine whether this exacerbation is caused by a mechanism involving altered iron status and to compare the influences of cystine and cysteine feeding on the defects of copper deficiency. Male Wistar rats were fed copper-adequate or copper-deficient diet with supplementation of L-cystine or L-cysteine ( $2 \%$ ) for 10 days or 21 days. Copper-deficient diet increased heart weight, caused anemia, reduced plasma iron and elevated liver iron. These defects were exacerbated by supplemental cystine. Cysteine feeding also exacerbated the defects of dietary copper deficiency including anemia, increased heart weight, and reduced plasma iron, although cysteine feeding had no influence on liver iron concentration. Supplemental cysteine reduced apparent absorption of iron, while supplemental cystine did not. These results suggest that cystine feeding enhances the defects of copper deficiency by a mechanism involving impaired mobilization of iron from liver into blood, and that cysteine feeding enhances the defects of copper deficiency by a mechanism involving reduced intestinal absorption of iron.
\end{abstract}

Key Words cystine, cysteine, copper deficiency, iron, ceruloplasmin

Dietary supplementation of cystine and methionine has been shown to exaggerate defects of dietary copper deficiency in rats (1). Dietary excess methionine has been shown to reduce tissue levels of copper in rats (2). There is also evidence that feeding excess methionine enhances tissue lipid peroxidation in rats (3). Since oxygen-derived free radical damage has been proposed as a mechanism for the defects of copper deficiency (4-6), excess methionine may exacerbates the defects of copper deficiency by a mechanism involving altered copper status and enhanced oxidative stress.

\footnotetext{
* To whom correspondence should be addressed.
} 
Recently, we have reported that while feeding excess cystine also enhanced signs of copper deficiency, it did not do so by altering copper status and enhancing oxidative stress (7). The mechanism of exacerbation of copper deficiency by cystine seemed to be different from that by methionine (7). The primary purpose of the present study was to elucidate the underlying mechanism of this exacerbation by cystine.

In our previous study, we found a reduced activity of serum ceruloplasmin in rats by dietary supplementation of cystine $(8,9)$. A physiological function of ceruloplasmin has been considered to relate to the mobilization of iron from liver to blood (10). Impairment of iron mobilization from liver associated with lower ceruloplasmin activity has been reported in copper deficiency (10). It has been considered that ceruloplasmin oxidizes $\mathrm{Fe}^{2+}$ to $\mathrm{Fe}^{3+}$ by its ferroxidase activity, which in turn leads to the binding of $\mathrm{Fe}^{3+}$ to transferrin. In view of these facts, we postulated that exacerbation of copper deficiency by cystine feeding might be mediated through impaired mobilization of iron from liver to blood.

In the present study, we tested the hypothesis that cystine feeding exacerbates the defects of copper deficiency by altering iron status. Since our recent study has shown that feeding cysteine-excessive diet has no influence on ceruloplasmin activity (9), the comparison of influences of feeding cystine and cysteine on dietary copper deficiency was also conducted. Although defects of copper deficiency such as anemia and increased heart size can be clearly observed in growing rats after feeding copper-deficient diet for one month or more, this study was conducted with shorter periods ( 10 or 21 days) since alteration in iron status by copper-deficient diet can be observed from these feeding periods (10).

\section{METHODS}

Animals and diets. Male Wistar rats weighing 100 to $120 \mathrm{~g}$ were obtained from Hiroshima Laboratory Animal Center (Hiroshima). The animal room was maintained at $24 \pm 1^{\circ} \mathrm{C}$ and illuminated for $12 \mathrm{~h}$ from $8: 00$ a.m. Rats consumed experimental diets and deionized water ad libitum for 10 days and 21 days. Animals were cared for in accordance with the guidelines established by Japanese Society of Nutrition and Food Science. The animals were fed on copper-adequate diet $(\mathrm{CuA})$ or copper-deficient diet $(\mathrm{CuD})$ with or without supplementation of sulfur-containing amino acids (Table 1). The composition of the basal diet was (in $\%$ of diet): $\alpha$-corn starch, 43.3; sucrose, 21.6; casein, 20; cellulose powder, 4; corn oil, 5; vitamin mixture (9), 2; salt mixture (11), 4; DL-methionine, 0.1. For the copper-deficient diets, $\mathrm{CuSO}_{4}$ was omitted from the salt mixture. The addition of L-cystine or L-cysteine ( $2 \%$ of diet, Katayama Chemical Co., Osaka) to copperadequate diet and copper-deficient diet was made at the expense of two parts of corn starch and one part of sucrose. Assay (see below) of copper concentration gave a range of 0.04 to $0.05 \mathrm{mg} \mathrm{Cu} / 100 \mathrm{~g}$ diet for the copper-deficient diets and a range of 1.57 to $1.63 \mathrm{mg} \mathrm{Cu} / 100 \mathrm{~g}$ for the copper-adequate diets. Assay of iron 
Table 1. Effect of dietary alteration of copper, cystine and cysteine on body weight and tissue weight.

\begin{tabular}{|c|c|c|c|c|c|c|}
\hline \multirow[t]{2}{*}{ Diet } & \multicolumn{2}{|c|}{$\begin{array}{l}\text { Body wt } \\
\text { (g) }\end{array}$} & \multicolumn{2}{|c|}{$\begin{array}{c}\text { Heart wt } \\
(\mathrm{mg} / \mathrm{g} \text { body wt) }\end{array}$} & \multicolumn{2}{|c|}{$\begin{array}{c}\text { Liver wt } \\
\text { (mg/g body } w t)\end{array}$} \\
\hline & 10 days & 21 days & 10 days & 21 days & 10 days & 21 days \\
\hline $\mathrm{CuA}$ & 191 & $281^{\mathrm{a}}$ & 3.5 & $2.9^{\mathrm{b}}$ & $50^{\mathrm{b}}$ & $47^{\mathrm{ab}}$ \\
\hline+ Cystine & 178 & $257^{\mathrm{ab}}$ & 3.5 & $3.0^{\mathrm{b}}$ & $55^{\mathrm{a}}$ & $50^{\mathrm{ab}}$ \\
\hline+ Cysteine & 184 & $262^{\mathrm{ab}}$ & 3.5 & $2.8^{\mathrm{b}}$ & $55^{\mathrm{a}}$ & $52^{\mathrm{ab}}$ \\
\hline $\mathrm{CuD}$ & 186 & $275^{\mathrm{ab}}$ & 3.7 & $3.1^{\mathrm{b}}$ & $48^{\mathrm{b}}$ & $48^{\mathrm{ab}}$ \\
\hline + Cystine & 176 & $253^{\mathrm{b}}$ & 3.7 & $3.4^{\mathrm{a}}$ & $55^{\mathrm{a}}$ & $54^{\mathrm{a}}$ \\
\hline + Cysteine & 180 & $259^{\mathrm{ab}}$ & 3.7 & $3.4^{\mathrm{a}}$ & $50^{\mathrm{b}}$ & $45^{\mathrm{b}}$ \\
\hline Pooled SEM & 1.4 & 2.9 & 0.05 & 0.04 & 0.6 & 1.0 \\
\hline Source of variation & \multicolumn{6}{|c|}{ Analysis of variance, $p$ values } \\
\hline $\mathrm{Cu}$ & NS & NS & NS & $<0.05$ & NS & NS \\
\hline Cystine & NS & $<0.05$ & NS & $<0.05$ & $<0.05$ & $<0.05$ \\
\hline Cysteine & NS & NS & NS & $<0.05$ & NS & NS \\
\hline $\mathrm{Cu} \times$ Cystine & NS & NS & NS & NS & NS & NS \\
\hline $\mathrm{Cu} \times$ Cysteine & NS & NS & NS & NS & NS & NS \\
\hline
\end{tabular}

$\mathrm{CuA}$, Copper-adequate diet; $\mathrm{CuD}$, Copper-deficient diet. Values are means of five rats per group and pooled SEM. Means not followed by the same letter are significantly different $(p<0.05)$ using Duncan's multiple range test. NS: Not significant.

concentrations gave a range of 3.9 to $4.0 \mathrm{mg} F e / 100 \mathrm{~g}$ diet. To prevent autooxidation of cysteine in the diet, cysteine was mixed with the basal diet daily at 7:00 p.m. $-8: 00$ p.m., and immediately the mixed diet was given to the animals. Feces were collected, and food intakes were measured from day 10 through day 14 . The fecal composites were dried to a constant weight and ground to a fine powder. At the end of the experimental period, animals were anesthetized with diethyl ether and killed between 1:00 p.m. and 3:00 p.m. Blood was collected by heart puncture with heparinized syringes, and plasma was separated by centrifugation.

Analytical procedures. Blood hemoglobin concentration was measured using a kit (Hemoglobin-Test Wako, Wako Pure Chemical Ind., Osaka). Plasma ceruloplasmin activity was measured by the method of Schösinsky et al. (12). Plasma levels of iron were measured by a kit (Fe-Test Wako, Wako Pure Chemical Ind.). Analysis of $\mathrm{Cu}$ and $\mathrm{Fe}$ in diets, tissues and feces was performed using a polarized Zeeman atomic absorption spectrophotometer (Model 180-60, Hitachi, Tokyo) as described previously (13). Estimates of hepatic lipid peroxidation were obtained by the determination of the concentration of thiobarbituric acid-reactive substances (TBARS) by the method described previously $(7,9)$. Data were subjected to two-way ANOVA for the various measurements. Duncan's multiple range test was used to determine differences in the data (14). Some data were analyzed by regression analysis. 


\section{RESULTS}

As shown in Table 1, an increased heart weight was observed in the groups fed copper-deficient diets supplemented with cystine and cysteine for 21 days compared with the other groups $(p<0.05)$, although dietary treatments for 10 days caused no influence on heart weight. Feeding cystine-supplemented diets for 10 days and 21 days caused an increase in liver weight $(p<0.05)$.

Rats fed copper-deficient diets for 21 days had significantly lower levels of hematocrit compared with animals fed copper-adequate diets (Table 2). Supplemental cystine and cysteine enhanced the reduction of hematocrit values by copper-deficient diet. Similar effects of dietary treatment for 21 days on hemoglobin levels were also observed. Lower levels of hemoglobin were observed in the animals fed copper-deficient diet supplemented with cystine for 10 days compared with other dietary treatment $(p<0.05)$. Reduced plasma concentrations of iron by copper-deficient diet were observed especially in the groups fed cystine- and cysteine-supplemented diets.

A marked depression in plasma ceruloplasmin activity was observed in the groups fed copper-deficient diets (Table 3). Supplemental cystine significantly reduced ceruloplasmin activity in copper-adequate rats, while supplemental cysteine

Table 2. Effect of dietary alteration of copper, cystine and cysteine on hematocrit, hemoglobin, and plasma iron.

\begin{tabular}{|c|c|c|c|c|c|c|}
\hline \multirow[t]{2}{*}{ Diet } & \multicolumn{2}{|c|}{$\begin{array}{c}\text { Hematocrit } \\
(\%)\end{array}$} & \multicolumn{2}{|c|}{$\begin{array}{l}\text { Hemoglobin } \\
(\mathrm{g} / \text { liter })\end{array}$} & \multicolumn{2}{|c|}{$\begin{array}{c}\text { Plasma iron } \\
(\mu \mathrm{M})\end{array}$} \\
\hline & 10 days & 21 days & 10 days & 21 days & 10 days & 21 days \\
\hline $\mathrm{CuA}$ & 39 & $41^{a}$ & $115^{\mathrm{a}}$ & $125^{\mathrm{a}}$ & $64^{\mathrm{a}}$ & $41^{a}$ \\
\hline+ Cystine & 37 & $40^{\mathrm{ab}}$ & $110^{\mathrm{a}}$ & $120^{\mathrm{ab}}$ & $54^{\mathrm{ab}}$ & $38^{\mathrm{ab}}$ \\
\hline+ Cysteine & 37 & $40^{\mathrm{ab}}$ & $111^{\mathrm{a}}$ & $121^{\mathrm{ab}}$ & $54^{\mathrm{ab}}$ & $35^{\mathrm{ab}}$ \\
\hline $\mathrm{CuD}$ & 38 & $38^{\mathrm{bc}}$ & $115^{\mathrm{a}}$ & $113^{\mathrm{bc}}$ & $55^{\mathrm{ab}}$ & $28^{\mathrm{ab}}$ \\
\hline + Cystine & 36 & $36^{\mathrm{c}}$ & $103^{\mathrm{b}}$ & $105^{\mathrm{cd}}$ & $29^{\mathrm{b}}$ & $18^{\mathrm{b}}$ \\
\hline+ Cysteine & 38 & $33^{d}$ & $110^{\mathrm{a}}$ & $100^{\mathrm{d}}$ & $38^{\mathrm{ab}}$ & $16^{\mathrm{b}}$ \\
\hline Pooled SEM & 0.4 & 0.5 & 0.7 & 1.3 & 3.4 & 2.4 \\
\hline Source of variation & \multicolumn{6}{|c|}{ Analysis of variance, $p$ values } \\
\hline $\mathrm{Cu}$ & NS & $<0.05$ & NS & $<0.05$ & $<0.05$ & $<0.05$ \\
\hline Cystine & NS & $<0.05$ & $<0.05$ & $<0.05$ & $<0.05$ & $<0.05$ \\
\hline Cysteine & NS & $<0.05$ & NS & $<0.05$ & $<0.05$ & $<0.05$ \\
\hline $\mathrm{Cu} \times$ Cystine & NS & NS & NS & NS & NS & NS \\
\hline $\mathrm{Cu} \times$ Cysteine & NS & NS & NS & NS & NS & NS \\
\hline
\end{tabular}

Values are means of five rats per group and pooled SEM. Means not followed by the same letter are significantly different $(p<0.05)$ using Duncan's multiple range test. NS: Not significant. 
Table 3. Effect of dietary alteration of copper, cystine and cysteine on ceruloplasmin, and liver trace elements.

\begin{tabular}{|c|c|c|c|c|c|c|}
\hline \multirow[t]{2}{*}{ Diet } & \multicolumn{2}{|c|}{$\begin{array}{l}\text { Ceruloplasmin } \\
\text { (U/liter) }\end{array}$} & \multicolumn{2}{|c|}{$\begin{array}{c}\text { Liver iron } \\
(\mu \mathrm{mol} / \mathrm{g} \text { tissue })\end{array}$} & \multicolumn{2}{|c|}{$\begin{array}{c}\text { Liver copper } \\
(\mu \mathrm{mol} / \mathrm{g} \text { tissue })\end{array}$} \\
\hline & 10 days & 21 days & 10 days & 21 days & 10 days & 21 days \\
\hline $\mathrm{CuA}$ & $94.8^{\mathrm{a}}$ & $124.8^{\mathrm{a}}$ & $1.03^{\mathrm{bc}}$ & $0.91^{\mathrm{c}}$ & $63^{\mathrm{a}}$ & $49^{\mathrm{a}}$ \\
\hline + Cystine & $71.9^{\mathrm{b}}$ & $99.0^{\mathrm{b}}$ & $0.87^{c}$ & $0.92^{\mathrm{c}}$ & $57^{\mathrm{a}}$ & $51^{\mathrm{a}}$ \\
\hline+ Cysteine & $92.4^{\mathrm{a}}$ & $128.8^{\mathrm{a}}$ & $0.76^{\mathrm{c}}$ & $0.81^{\mathrm{c}}$ & $50^{\mathrm{a}}$ & $46^{\mathrm{a}}$ \\
\hline $\mathrm{CuD}$ & $3.1^{\mathrm{c}}$ & $0.2^{\mathrm{c}}$ & $1.30^{\mathrm{b}}$ & $1.80^{\mathrm{b}}$ & $29^{\mathrm{b}}$ & $11^{\mathrm{b}}$ \\
\hline + Cystine & $1.4^{\mathrm{c}}$ & ND & $1.67^{\mathrm{a}}$ & $2.78^{\mathrm{a}}$ & $22^{\mathrm{b}}$ & $6^{\mathrm{b}}$ \\
\hline + Cysteine & $2.9^{c}$ & $0.5^{\mathrm{c}}$ & $1.03^{\mathrm{bc}}$ & $1.92^{\mathrm{b}}$ & $29^{\mathrm{b}}$ & $11^{\mathrm{b}}$ \\
\hline Pooled SEM & 1.3 & 4.3 & 0.030 & 0.066 & 1.6 & 1.1 \\
\hline Source of variation & \multicolumn{6}{|c|}{ Analysis of variance, $p$ values } \\
\hline $\mathrm{Cu}$ & $<0.05$ & $<0.05$ & $<0.05$ & $<0.05$ & $<0.05$ & $<0.05$ \\
\hline Cystine & $<0.05$ & $<0.05$ & $<0.05$ & $<0.05$ & NS & NS \\
\hline Cysteine & NS & NS & NS & NS & NS & NS \\
\hline $\mathrm{Cu} \times$ Cystine & $<0.05$ & $<0.05$ & $<0.05$ & $<0.05$ & NS & NS \\
\hline $\mathrm{Cu} \times$ Cysteine & NS & NS & NS & NS & NS & NS \\
\hline
\end{tabular}

Values are means of five rats per group and pooled SEM. Means not followed by the same letter are significantly different $(p<0.05)$ using Duncan's multiple range test. ND: Not detectable $(<0.1 \mathrm{U} /$ liter $)$. NS: Not significant.

did not. In copper-deficient rats, cystine feeding had no significant influence on ceruloplasmin activity. Copper-deficient diets caused elevation of liver iron. A marked accumulation of liver iron by copper-deficient diet was observed in the cystine-supplemented diet. The significant ANOVA $p$ values observed for interactions of the effects of cystine and copper on plasma ceruloplasmin and liver iron can also be explained by the marked effects of dietary cystine in copper-adequate rats and in copper-deficient rats, respectively. Cysteine feeding did not influence the liver iron concentration. There was no significant correlation between liver iron and ceruloplasmin level in copper-deficient animals $(r=-0.418, p>0.05$ for 10 days; $r=-458, p>0.05$ for 21 days). Copper-deficient diet reduced liver copper $(p<0.05)$, although dietary cystine and cysteine did not alter liver copper concentration.

Concentrations of iron in the heart, spleen and femur were significantly reduced in the rats fed copper-deficient diet for 21 days (Table 4). Dietary supplementation of cystine and cysteine had no influence on heart and femur iron in the animals fed the diets. A significant elevation in splenic iron by feeding cystine supplemented diet for 21 days was observed in the rats fed copper-adequate and copper-deficient diets. In the rats fed the experimental diets for 10 days, iron levels in heart, spleen and femur were unaffected by dietary manipulation.

A reduced apparent absorption of iron was observed with cysteine-supple- 
Table 4. Effect of dietary alteration of copper, cystine and cysteine on iron concentrations in heart, spleen and femur.

\begin{tabular}{|c|c|c|c|c|c|c|}
\hline \multirow[t]{2}{*}{ Diet } & \multicolumn{2}{|c|}{$\begin{array}{c}\text { Heart iron } \\
(\mu \mathrm{mol} / \mathrm{g} \text { tissue })\end{array}$} & \multicolumn{2}{|c|}{$\begin{array}{c}\text { Spleen iron } \\
(\mu \mathrm{mol} / \mathrm{g} \text { tissue })\end{array}$} & \multicolumn{2}{|c|}{$\begin{array}{c}\text { Femur iron } \\
(\mu \mathrm{mol} / \mathrm{g} \text { tissue })\end{array}$} \\
\hline & 10 days & 21 days & 10 days & 21 days & 10 days & 21 days \\
\hline $\mathrm{CuA}$ & 0.88 & $1.02^{\mathrm{a}}$ & 2.10 & $2.43^{\mathrm{c}}$ & 0.49 & $0.54^{\mathrm{a}}$ \\
\hline + Cystine & 0.90 & $0.97^{\mathrm{ab}}$ & 2.79 & $3.93^{\mathrm{a}}$ & 0.55 & $0.51^{\mathrm{a}}$ \\
\hline + Cysteine & 0.85 & $0.94^{\mathrm{ab}}$ & 2.25 & $3.73^{\mathrm{ab}}$ & 0.52 & $0.56^{\mathrm{a}}$ \\
\hline $\mathrm{CuD}$ & 0.87 & $0.88^{\mathrm{ab}}$ & 2.29 & $2.14^{\mathrm{c}}$ & 0.47 & $0.41^{\mathrm{b}}$ \\
\hline+ Cystine & 0.85 & $0.91^{\mathrm{ab}}$ & 2.09 & $2.97^{\mathrm{bc}}$ & 0.49 & $0.48^{\mathrm{ab}}$ \\
\hline+ Cysteine & 0.88 & $0.87^{\mathrm{b}}$ & 2.16 & $2.36^{\mathrm{c}}$ & 0.49 & $0.37^{b}$ \\
\hline Pooled SEM & 0.013 & 0.016 & 0.082 & 0.092 & 0.008 & 0.014 \\
\hline Source of variation & \multicolumn{6}{|c|}{ Analysis of variance, $p$ values } \\
\hline $\mathrm{Cu}$ & NS & $<0.05$ & NS & $<0.05$ & NS & $<0.05$ \\
\hline Cystine & NS & NS & NS & $<0.05$ & NS & NS \\
\hline Cysteine & NS & NS & NS & NS & NS & NS \\
\hline $\mathrm{Cu} \times$ Cystine & NS & NS & NS & NS & NS & NS \\
\hline $\mathrm{Cu} \times$ Cysteine & NS & NS & NS & NS & NS & NS \\
\hline
\end{tabular}

Values are means of five rats per group and pooled SEM. Means not followed by the same letter are significantly different $(p<0.05)$ using Duncan's multiple range test. NS: Not significant.

mented diets (Table 5). Neither dietary alteration of copper nor cystine supplementation affected the absorption of iron. Elevation in apparent absorption of copper was observed with copper-deficient diet. The absorption of copper was unaffected by supplemental cystine and cysteine.

In the rats fed experimental diets for 21 days, liver concentrations of TBARS were measured. The results showed $18-22 \%$ elevations in the concentrations of TBARS by copper-deficient diets $(p<0.05)$, but there was no alteration in TBARS levels by the supplementation of sulfur-containing amino acids $(p>0.05)$ (data not shown).

\section{DISCUSSION}

This study demonstrated that excess cystine feeding for only 10 days promoted the accumulation of liver iron and the reduction in plasma iron caused by copperdeficient diet. These responses seemed to precede the changes in heart weight, hematocrit and hemoglobin (Tables 1,2). These results support our hypothesis that cystine feeding exacerbates the defects of copper deficiency by a mechanism involving impaired mobilization of liver iron. The possibility has been suggested that mobilization of iron can be influenced by ferroxidase activity of serum ceruloplasmin and by the levels of ascorbic acid and xanthine oxidase in tissues $(10$, 
Table 5. Effect of dietary alteration of copper, cystine and cysteine on apparent absorption of copper and iron.

\begin{tabular}{lccc}
\hline \multicolumn{1}{c}{ Diet } & $\begin{array}{c}\text { Food intake } \\
(\mathrm{g} / 4 \text { days })\end{array}$ & $\begin{array}{c}\text { Absorption of Fe } \\
(\%)\end{array}$ & $\begin{array}{c}\text { Absorption of } \mathrm{Cu} \\
(\%)\end{array}$ \\
\hline CuA & 97 & $54^{\mathrm{a}}$ & $33^{\mathrm{b}}$ \\
+ Cystine & 89 & $46^{\mathrm{a}}$ & $29^{\mathrm{b}}$ \\
+ Cysteine & 88 & $37^{\mathrm{b}}$ & $30^{\mathrm{b}}$ \\
CuD & 97 & $49^{\mathrm{a}}$ & $82^{\mathrm{a}}$ \\
+ Cystine & 89 & $55^{\mathrm{a}}$ & $61^{\mathrm{a}}$ \\
+ Cysteine & 88 & $38^{\mathrm{b}}$ & $65^{\mathrm{a}}$ \\
\hline Pooled SEM & 1.5 & 1.4 & 2.8 \\
\hline Source of variation & \multicolumn{4}{|c}{} \\
\hline Cu & Analysis of variance, $p$ values \\
Cystine & $\mathrm{NS}$ & $\mathrm{NS}$ & $<0.05$ \\
Cysteine & $\mathrm{NS}$ & $\mathrm{NS}$ \\
Cu $\times$ Cystine & $\mathrm{NS}$ & $<0.05$ & $\mathrm{NS}$ \\
Cu $\times$ Cysteine & $\mathrm{NS}$ & $\mathrm{NS}$ & $\mathrm{NS}$ \\
\hline
\end{tabular}

Values are means of five rats per group and pooled SEM. Means not followed by the same letter are significantly different $(p<0.05)$ using Duncan's multiple range test. NS: Not significant.

15). Our data indicated that, although cystine feeding significantly reduced ceruloplasmin activity in copper-adequate animals, cystine feeding caused only a trend in the reduction of ceruloplasmin activity in copper-deficient animals (Table 3 ). The correlation coefficients between liver iron and ceruloplasmin activity in copper-deficient rats were also low (statistically not significant). Thus, we failed to show an association between alteration in liver iron by cystine and ceruloplasmin level. The possibility that alteration in iron mobilization by cystine absolutely depends on an altered ceruloplasmin level appears to be negated. Our recent study has shown that feeding of the diet supplemented with $2 \%$ cystine for 20 days had no significant influence on the hepatic concentration of ascorbic acid or xanthine oxidase activity in rats compared with feeding of the diet without supplementation of cystine (Kato et al. unpublished data). Thus, it is unlikely that the effect of cystine feeding on iron status is mediated through altering tissue ascorbic acid and xanthine oxidase.

Our study further showed an accumulation of splenic iron by cystine feeding for 21 days, although in the animals fed the diets for 10 days the splenic iron concentration was unaffected by dietary manipulation (Table 5). This accumulation of iron by cystine might also at least partially relate to reduced plasma iron and exacerbation of copper deficiency. Since altered distribution of the size of red blood cells in rats fed cystine-excessive diet has been observed (7), cystine feeding for a prolonged period might cause hemolysis leading to the accumulation of splenic iron 
and exacerbation of anemia.

Consistent with our previous study (9), cysteine feeding caused no alteration in ceruloplasmin activity, although the reason for the differential responses of ceruloplasmin to dietary cystine and cysteine is unknown. Interestingly, cysteine feeding also exacerbated the defects of copper deficiency involving anemia, reduced plasma iron and increased heart weight; although, in contrast to cystine feeding, cysteine feeding had no influence on the concentrations of iron in the liver or spleen of rats fed copper-deficient diet. Reduced absorption of iron by cysteine feeding was also observed (Table 5). From these facts, we speculate that exacerbation of the defects of copper deficiency is at least in part ascribed to lower intestinal absorption of iron. As well as cystine feeding, cysteine feeding had no influence on the hepatic concentrations of TBARS, suggesting that an enhancement of copper deficiency by supplemental cysteine is not mediated through a mechanism involving oxidative stress.

The major metabolic fate of cystine in mammals is conversion to cysteine, and catabolism of cystine then merges with that of cysteine (16). The same effect of cystine and cysteine on the growth of chicks (17) and rats (Kato et al. to be published) has been observed. From these facts, it seemed that these two amino acids are nutritionally equivalent. However, our studies in this report and a previous report (9) have demonstrated differential responses of ceruloplasmin and of the metabolism of iron and cholesterol to these two amino acids. Further study in our laboratory will be focused on the underlying mechanisms of these differential metabolic responses.

The authors wish to acknowledge Dr. Jack T. Saari of the USDA-ARS Grand Forks Human Nutrition Research Center for helpful comments and suggestions during the preparation of this manuscript.

\section{REFERENCES}

1) Nielsen, F. H. (1988): Sulfur amino acid nutriture affects the signs of copper deficiency in the rat. J. Trace Elem. Exp. Med., 1, 157-166.

2) Strain, J. J., and Lynch, S. M. (1990): Excess dietary methionine decreases indices of copper status in the rat. Ann. Nutr. Metab., 34, 93-97.

3) Lynch, S. M., and Strain, J. J. (1989): Increased hepatic lipid peroxidation with methionine toxicity in the rat. Free Rad. Res. Comms., 5, 221-226.

4) Paynter, D. I. (1980): The role of dietary copper, manganese, selenium, and vitamin E in lipid peroxidation in tissues of the rat. Biol. Trace Elem. Res., 6, 379-391.

5) Saari, J. T. (1989): Chronic treatment with dimethyl sulfoxide protects against cardiovascular defects of copper deficiency. Proc. Soc. Exp. Biol. Med., 190, 121-124.

6) Saari, J. T., Dickerson, F. D., and Habib, M. P. (1990): Ethane production in copper-deficient rats. Proc. Soc. Exp. Biol. Med., 195, 30-33.

7) Kato, N., Saari, J. T., and Schelkoph, G. M. (1994): Cystine feeding enhances defects of dietary copper deficiency by a mechanism not involving oxidative stress. J. Nutr. 
Biochem., 5, 99-105.

8) Yang, B.-S., Katayama, T., and Kato, N. (1993): Responses of tissue ascorbic acid and of serum cholesterol, $\alpha$-tocopherol, and ceruloplasmin in rats to dietary level of cystine. J. Nutr. Sci. Vitaminol., 39, 497-506.

9) Yang, B.-S., Wan, Q., and Kato, N. (1994): Differential effects of dietary excessive cystine and cysteine on plasma ceruloplasmin and cholesterol in rats. Biosci. Biotech. Biochem., 58, 1177-1178.

10) Evans, J. L., and Abraham, P. A. (1973): Anemia, iron storage and ceruloplasmin in copper nutrition in the growing rat. J. Nutr., 103, 196-201.

11) Ebihara, K., Imamura, Y., and Kiriyama, S. (1979): Effect of dietary mineral composition on nutritional equivalency of amino acid mixtures and casein in rats. $J$. Nutr., 109, 2106-2116.

12) Schösinsky, K. H., Lehmann, H. P., and Beeler, M. F. (1974): Measurement of ceruloplasmin from its oxidase activity in serum by use of $o$-dianisidine dihydrochloride. Clin. Chem., 20, 1556-1563.

13) Katayama, T., Ohara, K., Kushuhara, T., Momota, Y., and Kato, N. (1989): Influence of copper deficient diet on the metabolic changes in rats exposed to PCB. Nutr. Rep. Int., 39, 963-971.

14) Duncan, D. B. (1957): Multiple range test for correlated and heteroscedactic means. Biometrics, 13, 164-176.

15) Cohen, N. L., Keen, C. L., Lönnerdal, B., and Hurley, L. S. (1985): Effects of varying dietary iron on the expression of copper deficiency in the growing rat: anemia, ferroxidase I and II, tissue trace elements, ascorbic acid, and xanthine oxidase. $J$. Nutr., 115, 633-639.

16) Cooper, A. J. L. (1983): Biochemistry of sulfur-containing amino acids. Ann. Rev. Biochem., 52, 187-222.

17) Orth, M. W., Bai, Y., Zeytun, I. H., and Cook, M. E. (1992): Excess levels of cysteine and homocysteine induce tibial dyschondroplasia in broiler chicks. J. Nutr., 122, 482487. 